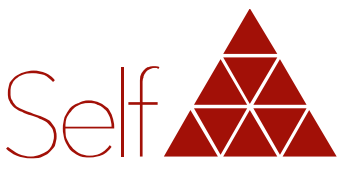

Revista do Instituto Junguiano de Săo Paulo

\title{
A ilha
}

Grandes cabeças puras, de longos pescoços, de olhar grave, gigantescas mandíbulas erguidas no olhar de sua solidão, presenças, presenças arrogantes, preocupadas.

Oh graves dignidades solitárias, quem se atreveu, se atreve a perguntar, a interrogar as estátuas interrogadoras?

São a interrogação disseminada que ultrapassa a estreiteza exata, a pequena cintura da ilha e se dirige ao grande mar, ao fundo do homem e de sua ausência. (Neruda, 1981, p. 41)

Finalmente nós nos encontramos do outro lado da ilha.

O planeta Terra é uma ilha, ilha imersa no espaço-tempo einsteiniano, o tecido do universo em que tudo existe. E apesar dessa imensidão inconquistável, somente há pouco - ainda agora, para bem dizer - nos demos conta de que o nosso mundo possui um limite, um limite físico. Nos demos conta de que nossos recursos naturais possuem limites mensuráveis e de que hoje é possível prever com alguma consistência quando irão acabar as reservas de combustível fóssil, quando não mais existirão tigres e leões vivendo livremente na natureza, até quando existirão pandas gigantes, orangotangos, abelhas...

Vivemos hoje o paradoxo de uma sociedade que tende a atribuir vida anímica a máquinas que nós mesmos construímos (num ritmo alucinante: cada vez mais parecidas conosco), uma sociedade que atribui dignidade aos seus pets e ao mesmo tempo consome o planeta, destruindo o lar de outros 
seres vivos, especialmente nossos primos primatas, cujo olhar é tão parecido com o nosso.

Repetimos, em enorme medida, o agir dos antigos habitantes da llha de Páscoa, o Umbigo do Mundo. Eles, afinal, como nós, construíram monumentos a si mesmos e às forças inconscientes e conscientes que os possuíam: os espíritos dos ancestrais mortos de um lado, o forte impulso humano pelo poder, do outro. $\bigcirc$ desejo de erguer símbolos que representem legados e, em última análise, imortalidade, comove o ser humano desde sempre. $\bigcirc$ impulso de construir o maior, o melhor, o mais importante monumento levou os rapanui a destruir o seu mundo, ao cortar quase todas as árvores da ilha, a fim de transformá-las em roletes para arrastar os impressionantes moai.

Muitos de nós ainda vivem a ilusão de que as fronteiras físicas dos países para sempre poderão ser ampliadas: a fantasia da consciência de que comportamentos excludentes (e, por isso mesmo, preconceituosos e supremo paradoxo depois dos horrores das Grandes Guerras - racistas) são aceitáveis, como se, neste mundo insular no qual existimos hoje, uns pudessem sobreviver à destruição de todos os outros.

Nunca precisamos tanto de alteridade e empatia. Nos multiplicamos tanto e tivemos tanto sucesso material que hoje a ilha começa a se tornar pequena: passamos a vasculhar o espaço com ansiedade, em busca de planetas semelhantes ao nosso. Temos medo de que não sejamos capazes de encontrar soluções para a distribuição do chão-lar e dos recursos-vida de maneira minimamente universal e justa.

Ventos retrógrados sopram por esse nosso mundo-ilha, proferindo discursos sectários que ainda se apegam à ideia tola de que um mundo de muros e taxas e egos exagerados, ocupando o lugar do Grande Irmão, possa gerar proteção e segurança, enaltecendo nacionalismos e outros "ismos", enquanto a atmosfera escurece, a camada de ozônio se esvai, o mundo ao redor aquece, pessoas pacíficas se tornam refugiados e refugiados não encontram refúgio, e as outras pessoas pacíficas pacificamente continuam a silenciar diante da dor alheia.

Jung sempre e sempre reafirmou o perigo das atitudes exageradas, frutos da arrogância da consciência e - outro paradoxo da natureza (na verdade, outro entre muitos) - da extrema vulnerabilidade a conteúdos inconscientes, primitivos e mesmo animalescos, aos quais esta consciência arrogante se expõe como resultado imprevisto da sua própria arrogância. E também praticamente gritou sobre como estes conteúdos primitivos inconscientes podem ser altamente contaminantes quando alcançam livremente a coletividade humana. Esse é certamente o perigo que vivemos agora.

Mas devemos observar com atenção que o recorte do momento que ora vivemos vem como reação a outros ventos, fortes ventos que já vinham antes a soprar pelo mundo, ventos de tolerância, ventos de acolhimento às diferenças, ventos em cujo bojo viajam ideias como a da dignidade - o 
caráter único e sagrado da vida humana - de cada uma das pessoas que vivem nesta ilha espacial e também daquelas que já se foram, nossos mortos e seu legado, sua honra por terem participado da saga humana: eles, que nos honram por existirem em nós.

Self, a revista do Instituto Junguiano de São Paulo, assim como toda a comunidade junguiana do Brasil e do mundo são daqueles que buscam na essência do ser humano, sem excluir um único que seja, a resposta para esse aparente dilema moderno que vivemos: desde o final da Segunda Grande Guerra, com a expressão na consciência coletiva de que cada pessoa humana é única e digna em sua diversidade, exatamente quando passamos a ver com alguma esperança um futuro mais amoroso, justo e democrático, espalham-se esses ventos extremistas e violentos pelo mundo. Jung diria que a todo bem corresponde um mal equivalente e que seus movimentos se modulam mutuamente; pareço ouvi-lo.

Em "Civilização em transição" (boa parte escrito no período entre guerras, ou como sugerem modernos pensadores, no intervalo da Grande Guerra), Jung dá uma resposta à questão sobre o que fazer:

São poucos os modernos, ou melhor, os homens que vivem no presente imediato, pois sua existência exige a mais alta consciência, uma consciência extremamente intensiva e extensiva, com um mínimo de inconsciência, pois só aquele que tem consciência plena de sua existência como ser humano está de todo presente. Deve-se entender bem que não é o simples fato de viver no presente que faz alguém ser moderno, pois neste caso tudo o que vive hoje seria moderno. Só é moderno aquele que tem profunda consciência do presente. (Jung, 2000, p. 75, OC X/3: 149)

\section{Ricardo Pires de Souza}

Editor científico

\section{Referências}

Jung, C. G. (2000). Civilização em transição. In C. G. Jung, Obras Completas (Vol. X/3). Petrópolis: Ed. Vozes.

Neruda P. (1981). A Rosa Separada. Porto Alegre: L\&PM Editores. 